\title{
Improvement of organic matter removal in water produced of oilfields using low cost moringa peels as a new green environmental adsorbent
}

\author{
Ahmed S.N. ${ }^{1 *}$, Ali S.J. ${ }^{2}$, Al-Zubaidi H.A.M. ${ }^{3}$, Ali A.H. ${ }^{2}$ and Ajeel M.A. ${ }^{4}$ \\ ${ }^{1}$ College of Water Resource Engineering, AL-Qasim Green University, Babylon 51031, Iraq \\ ${ }^{2}$ Chemical Engineering Department, College of Engineering, University of Al Muthanna, Iraq \\ ${ }^{3}$ Department of Environmental Engineering, College of Engineering, University of Babylon, Babylon, Iraq \\ ${ }^{4}$ Department of Environment, Faculty of Environment and Energy, Al-Karkh University of Science, Iraq \\ Received: 09/03/2019, Accepted: 06/07/2020, Available online: 14/07/2020 \\ *to whom all correspondence should be addressed: e-mail: ahmednamesamir@yahoo.com \\ https://doi.org/10.30955/gnj.003098
}

\section{Graphical abstract}
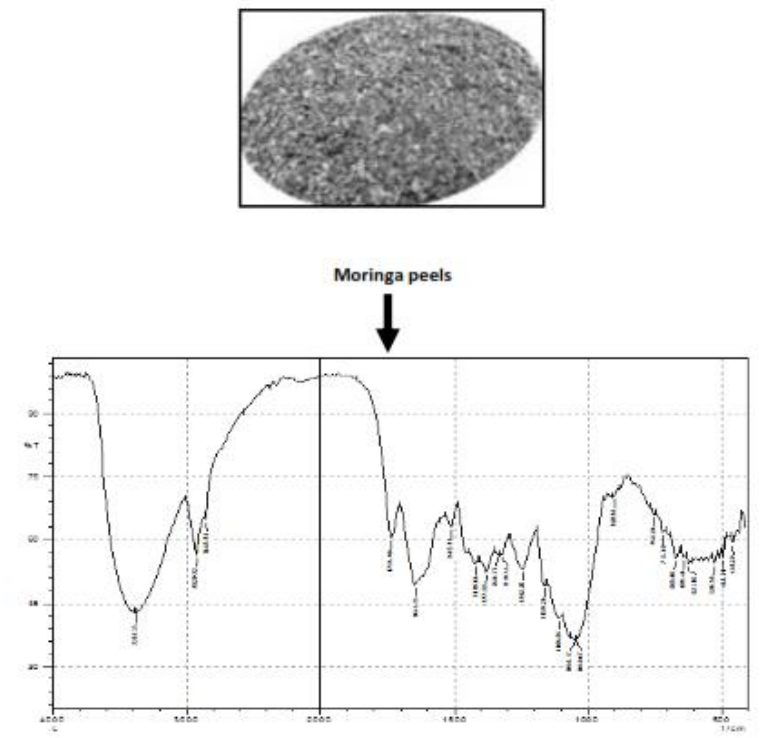

FTIR analysis of moringa peels before adsorption for $0.075 \mathrm{~mm}$ $\downarrow$
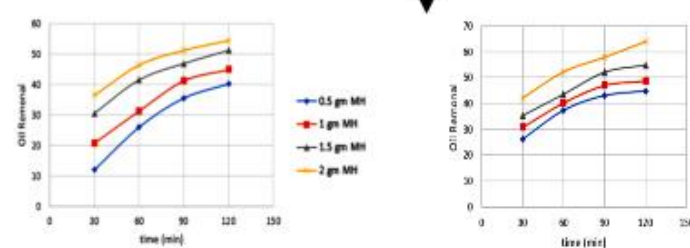

$\rightarrow-250$ OANH

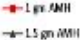
$-2 \pi / 11$

Moringa peels products Ecofriendly adsorbents

- Low cost

High removal efficiency

\section{Abstract}

The present study observed the evaluation of organic content removal from produced water by adsorption onto moringa and activated moringa peels. the removal of the organic content from the real effluent water produced by the oilfields. The proposed treatment process was the adsorption technique using the moringa peels as adsorbing agent. The effect of some parameters such as: adsorbent dose, $\mathrm{pH}$ and contact time on adsorption process has been investigated using the batch adsorption method. FTIR spectral examination shows a presence the bands of carboxyl, hydroxyl and amine on the surface of MH. FT-IR device type shimadzu $\left(4000-400 \mathrm{~cm}^{-1}\right)$ was approved out to classify the functional groups and structural in the moringa peels that strength be complicated in the biosorption process. The Langmuir isotherm provided a better fit for the adsorption equilibrium data than the Freundlich isotherm. It was observed that organic content adsorption was dependent on $\mathrm{pH}$. The maximum removals of organic content were $65.4 \%$ and $94.1 \%$ for moringa and activated moringa peels respectively at $\mathrm{pH}=3,120 \mathrm{~min}, 1.5 \mathrm{gm}$ dose. The outcome of this study exposes that the moringa and activated moringa peels are ecofriendly adsorbents can suggest for the treatment of produced water. In addition, moringa peels are available in large amount and its treatment technique is very economical.

Keywords: Oilfields, produced water, organic material, moringa peels, adsorption.

\section{Introduction}

Like most production activities, during crude oil extraction process, water from the reservoir gas and oil production processes generate huge amounts of liquid waste identified by means of produced water (PW) (Boudrahem et al., 2015). PW is the main waste stream produced in oil and gas trades. Produced water comprises of a diverse mixture of organic and inorganic chemicals, cations (e.g. magnesium, calcium and iron), anions (e.g. carbonate and bromide sulfate) and other components such as heavy metals (e.g. barium, uranium, cadmium, chromium and lead) (Li et al., 2005),(Ali A. Hassan et al., 2018). Discharging produced water to environment lead to contaminate soil, surface and underground water (Fakhru'l-Razi et al., 2009). 
Furthermore, release of the produced water with high chemical oxygen demand (COD) value has harmful ecological penalties. However, many countries were implemented a severe guidelines for discharging a least level permissible of their produced water (Aziz and Daud, 2012). The release of huge amounts of contaminated waste water to the environment motivates the researchers to develop different techniques and implementing appropriate treatment skills, capable of eliminating dangerous pollutants present in numerous of oil and gas manufacturing streams (Hernández-Francisco et al., 2017)(Diya'uddeen et al., 2011). Treatment of these wastes might result in enhanced water quality, water reclaim, oil recovery, defense of downstream amenities and ecological permit obedience (Okiel et al., 2011). PW is treated by numerous physical means earlier release and rules put severe restrictions on levels of pollutants which can be discharged to the sea (Bakke et al., 2013). Presently, properly preserved water can be recycled and used for water inundating. These helpful recycles directly reduces the withdrawal of potable water, an extremely appreciated commodity in numerous areas of the biosphere (Fathy et al., 2017). The elimination of organic residual from oilfield produced water has been attained by numerous processes such as a phase separator (Almarouf et al., 2015), sedimentation (Mohammed and Shakir, 2017), coagulation/flocculation (Amuda and Amoo, 2007), (Khalid M. Mousa and Ali. A. Al-Hasan, 2017), electrocoagulation (Fouad, 2014), flotation(da Silva et al., 2015), filtration and membrane processes (Zoubeik et al., 2017)-(Zsirai et al., 2018), biological operations (Benitez et al., 2001) and chemical processes (Saien and Nejati, 2007)-(Lee and Park, 2013). Most of these approaches suffers from some drawbacks such as the high capital or operative cost and there are difficulties in disposal of remaining organic sludge (Al-Othman et al., 2012). In contrast, the adsorption method has developed one of the most favored methods for the elimination of organic owing to its high competence and low cost. Various agricultural products had straight been used as adsorbent for organic adsorption from waste water which comprised Palm fibers (Abdelwahab et al., 2017), banana peels (El-Din et al., 2017), bentonite (Okiel et al., 2011) soybean hull (Steevensz et al., 2014), olive (AlAnber and Al-Anber, 2008), barley straw (Ibrahim et al., 2010), cocoa shells (Fiset et al., 2002), tea leaves (Ahsan et al., 2018) and orange peels (AbdurRahman et al., 2013). Activated carbon is showed to be an active adsorbent in waste treatment process. Though, there is a possibility to discover an available and inexpensive sorbents from agro-industrial origin (Ratnamala et al., 2016). Moringa peels are non-toxic usual organic polymer. The tree is usually recognized in the emerging world as medicinal plant, herbal, and a foundation of vegetable oil (Vieira et al., 2010). The aim of this work is to evaluate organic content removal from produced water by adsorption onto moringa and activated moringa peels. The effect of some parameters such as: adsorbent dose, $\mathrm{pH}$ and contact time on adsorption process has been considered.

\section{Materials and methods}

\subsection{Preparation of moringa peels}

Moringa peels $(\mathrm{MH})$ used in the current study was collected from Iraqi farms. The $\mathrm{MH}$ was crumpled and dried in the sunlight for 48 hour and used as a fresh adsorbent. The dried peels were preserved with $\mathrm{HCL}$ concentration for 4 hour and then wash methodically with distilled water till it reached neutral $\mathrm{pH}$, then the adsorbent peels were washed with distilled water. AMH used as adsorbent was prepared according to a procedure that described in literature (Bello et al., 2017). The dried $\mathrm{MH}$ were carbonized in the department of chemical Laboratory of Al-Muthanna University, Iraqi. $100 \mathrm{gm}$ of the dried moringa peels was heated in a muffle furnace (Mikrotex, Turkey) set at $250{ }^{\circ} \mathrm{C}$ for $2 \mathrm{~h}$. Throughout, the procedure, the moringa peels was thermally disintegrated to absorbent materials and hydrocarbon compounds. The activated samples were rinsed with distilled water until the neutral $\mathrm{pH}$ and then keep them at room temperature. The washed activated moringa peels dried later in an oven at $110{ }^{\circ} \mathrm{C}$. The carbonized moringa peels were sieved with $0.075 \mathrm{~mm}$ mesh sieve (Besmak sieves from $2.36 \mathrm{~mm}$ to $0.075 \mathrm{~mm}$ ). The specific surface area of $\mathrm{MH}$ and $\mathrm{AMH}$ is estimated Brunauer Emmat and Teller (BET) technique, whereas, the $\mathrm{MH}$ and $\mathrm{AMH}$ is strongly minded through a micrometric apparent (ASAP, 2010) via nitrogen adsorption at $77 \mathrm{~K}$.

\subsection{Experimental procedure}

The produced water (PW) was collected from Al-Ahdab oilfield, located in Iraqi. The waste was exposed to filtration to eliminate most of its total solids then reserved at $5{ }^{\circ} \mathrm{C}$, to safeguard that its characteristics of waste water will not be tapering or weathered. The description of produced water is assumed in Table 1.

Table 1. Characteristics of produced water (PW)

\begin{tabular}{cc}
\hline Parameter & value \\
\hline Oil & $210(\mathrm{ppm})$ \\
\hline Turbidity & $85.64 \mathrm{NTU}$ \\
\hline $\mathrm{pH}$ & 6.2 \\
\hline Solution oxygen content & $0.053(\mathrm{ppm})$ \\
\hline Specific gravity & 0.998 \\
\hline conductivity & $70688.64 \mathrm{\mu s} / \mathrm{cm}$ \\
\hline TDS & $64346.24(\mathrm{ppm})$ \\
\hline Viscosity & $1.301 \mathrm{~m} \mathrm{~Pa} / \mathrm{S}$ \\
\hline İron & $0.36(\mathrm{ppm})$ \\
\hline Sulphate & $65.2(\mathrm{ppm})$ \\
\hline TSS & $20 \mathrm{ppm}$ \\
\hline Manganese & $2.5 \mathrm{ppm}$ \\
\hline Chrome & $0.15 \mathrm{ppm}$ \\
\hline
\end{tabular}

The organic adsorption tests were performed by a batch technique. The PW was agitated by responding shaker at room temperature $\left(25 \pm 2{ }^{\circ} \mathrm{C}\right)$ with $130 \mathrm{rpm}$. Samples were occupied at limited intervals and then filtered with Whatman No. 2041 filter paper $(150 \mathrm{~mm})$. The filtrates were examined for remaining organic content in the PW. The influence of the solution $\mathrm{pH}$ on the organic sorption performance was examined in the similar way but that the initial $\mathrm{pH}$ of the solutions was adjusted to values varying from 2.0 to 10.0 with the adding of either $0.1 \mathrm{M} \mathrm{NaOH}$ or $0.1 \mathrm{M} \mathrm{H}_{2} \mathrm{SO}_{4}$, the $\mathrm{pH}$ values were also recorded after the 
moringa husks-organic suspensions had reached equilibrium. Different amounts of $\mathrm{MH}$ and $\mathrm{AMH}$ in the range (0.5-2 $\mathrm{mg}$ ) were added to $\mathrm{PW}$ solution. The quantity of PW at equilibrium $\left(\mathrm{q}_{\mathrm{e}}\right)$ was estimated using an assumed mass balance equation as below (Ali Saleh Jafer et al., 2019):

$$
q_{e}=V\left(C_{\mathrm{o}}-C_{\mathrm{e}}\right) / M
$$

where $\mathrm{q}_{\mathrm{e}}(\mathrm{mg} / \mathrm{g})$ is the total of organic in PW per mass unit of watermelon absorbent at certain time $t, V$ is the solution volume $\left(\mathrm{cm}^{3}\right), \mathrm{M}$ is the mass of adsorbent $(\mathrm{mg})$ and $\mathrm{C}_{0}$ and $\mathrm{C}_{\mathrm{e}}(\mathrm{ppm})$ are the original and at time t concentration of PW correspondingly. The oil elimination by $\mathrm{MH}$ and $\mathrm{AHM}$ was estimated at each equilibration by the following equation as:

$$
\text { Adsorption }(\%)=\left(C_{0}-C_{t}\right) / C_{0} \times 100
$$

\subsection{Chemical analysis and tools}

The organic content of oilfield produced water was monitored by a UV-spectra meter (UV-1800 Shimadzu, Japan) spectrophotometer associated to a PC at maximum absorption wavelength (312 nm). The turbidity was estimated using turbid meter (Lovibond, SN 10/1471, and Germany). The $\mathrm{pH}$ measurements were performed by $\mathrm{pH}$ meter (Model 2906, Jenway LTd, UK). All chemicals used in this study are an analytical grade, $\mathrm{H}_{2} \mathrm{SO}_{4}$ (98\% purity), $\mathrm{NaCL}$ and $\mathrm{NaOH}$ (98\% purity) were purchased from India. Oil was Tested using a UV-spectra meter, where $\mathrm{NaCl}(0.25 \mathrm{mg}$ ) was added to $50 \mathrm{~mL} P W$ in the unraveling funnel with the intention of disruption the emulsion of organic. $5 \mathrm{ml}$ of $\mathrm{CCL}_{4}$ was supplementary and shadowed by vigorous shaking for $1 \mathrm{~min}$. After $25 \mathrm{~min}$, once the solution separated into two separate layers, the inferior (organic) layer was occupied for the absorbance dimension, and after the calibration curve, organic content in PW was found. The characterization of $\mathrm{CCL}_{4}$ is given in Table 2 .

Table 2. Properties of $\mathrm{CCl}_{4}$ solvent

\begin{tabular}{cc}
\hline Property & Value \\
\hline Physical state & Liquid \\
\hline Molecular weight & 153.82 \\
\hline Color & Colorless \\
\hline Odor & Aromatic, sweet \\
\hline Melting point & $-23^{\circ} \mathrm{C}$ \\
\hline Boiling point & $76.5^{\circ} \mathrm{C}$ \\
\hline Formula & $\mathrm{CCl}_{4}$ \\
\hline Purity & $99 \%$ \\
\hline
\end{tabular}

\section{Results and discussion}

\subsection{FTIR analysis}

The natural moringa peels functional groups characterized using FTIR measurements with spectra in the variety of $4000-400 \mathrm{~cm}^{-1}$ as shown in Figure 1. FTIR spectral examination shows a presence the bands of carboxyl, hydroxyl and amine on the surface of $\mathrm{MH}$. FT-IR device type shimadzu $\left(4000-400 \mathrm{~cm}^{-1}\right)$ was approved out to classify the functional groups and structural in the moringa peels that strength be complicated in the bio-sorption process. The comprehensive band at $3381.33 \mathrm{~cm}^{-1}$ in moringa peels is credited owing to hydroxyl $(-\mathrm{OH})$ stretching or amine ($\mathrm{NH}_{2}$ ) widening of polymeric compounds. This band seemed in the inferior region $2920.32-2852.81 \mathrm{~cm}^{-1}$ in the FTIR spectra of $\mathrm{MH}$ and it is credited to the attendance of the C$\mathrm{H}$ bond. The $\mathrm{C} \mathrm{O}$ widening of moringa peels by away at $1735.99 \mathrm{~cm}^{-1}$ (Kebede et al., 2019). The C O widening removed to higher incidence as a result of participation of carboxyl ( $-\mathrm{C} \mathrm{O})$ group during adsorption process of the organic content with $\mathrm{MH} .1510 .31 \mathrm{~cm}^{-1}$ indicates to the aromatic rings, while 1419.66 and $1377.22 \mathrm{~cm}^{-1}$ related with the $\mathrm{C}-\mathrm{O}$ of phenols and $-\mathrm{CH}_{3}$ correspondingly. Then the bands less than $800 \mathrm{~cm}^{-1}$ are finger print zone of phosphate and sulphur functional groups (Ali Saleh Jafer et al., 2019).

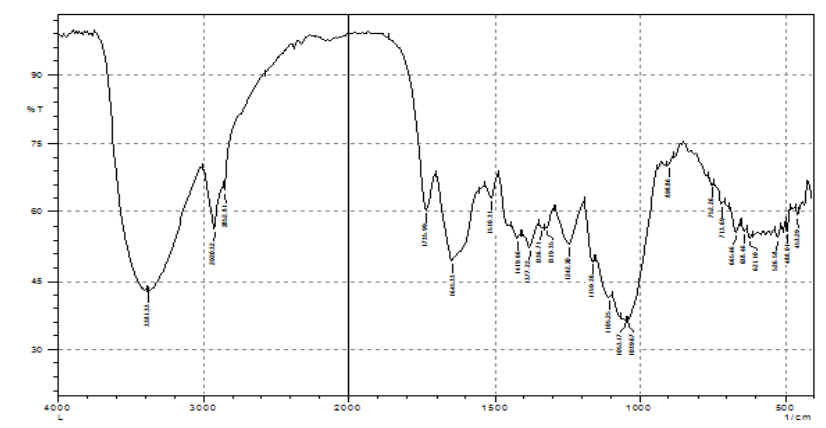

Figure 1. FTIR analysis of moringa peels before adsorption for $0.075 \mathrm{~mm}$.

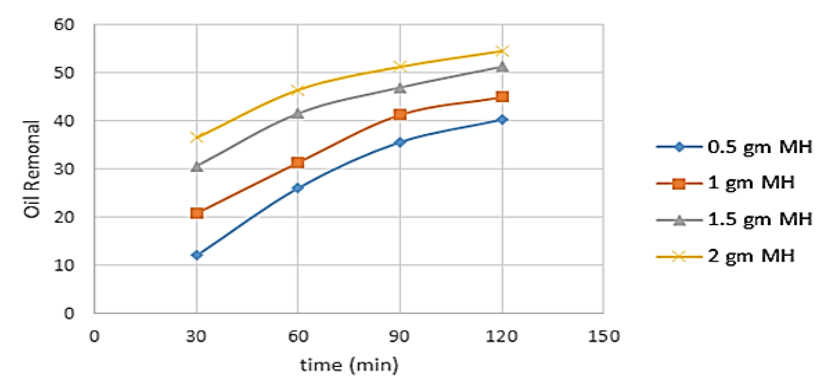

Figure 2. Effect of dosage on organic removal in $0.075 \mathrm{~mm}$ moringa peels size, $\mathrm{pH}=6.2$, room temperature.

\subsection{Effect of moringa peels doses}

Wide range of dosages has been used $0.5-2 \mathrm{mg}$ to investigate the removal of organic content from $\mathrm{PW}$ solution by $\mathrm{MH}$ and AHM. In these series of trials, the adsorbent dosages effect on the produced water by the moringa and activated moringa peels are exposed in Figures 2 and 3. It is obvious, the increase of adsorbent dosages has a significant impact on the process performance. Whereas, the raised of $\mathrm{MH}$ and $\mathrm{AMH}$ dosages from 0.5 to $2 \mathrm{mg}$ led to improve the removal percent from $40.2 \%, 44.5 \%$ to $54.5 \%$, and $64 \%$ respectively. This may be attributed to the fact that availability of exchangeable sites for the pollutants increases with an increase in the adsorbent dosage. However, the increased of $\mathrm{MH}$ and $\mathrm{AMH}$ doses from 1.5 to $2 \mathrm{mg}$ didn't have a significant effect on the removal efficiency of organic pollutant for both adsorbents ( $\mathrm{MH}$ and $\mathrm{AMH}$ ) used. The acceptance of PW that (organic content) augmented with upsurge in the 
adsorbent ( $\mathrm{HM}$ and $\mathrm{AHM}$ ) doses can be credited to the increase of surface area, active sites, pores, the number of unsaturated places and the adsorption places (Gupta et al., 2016).

A similar tendency was stated by Rehab M (2016) in his studies about removal of heavy metal from aqueous solution by peanut hull (Ali et al., 2016). Furthermore, the removal efficiency of organic pollutant from $\mathrm{PW}$ when use the AHM adsorbent was higher than that of HM adsorbent. This marked is attributed to the AHM adsorbent has a specific surface area $\left(913 \mathrm{~m}^{2} / \mathrm{g}\right)$ which higher than that of $\mathrm{HM}\left(713 \mathrm{~m}^{2} / \mathrm{g}\right)$.

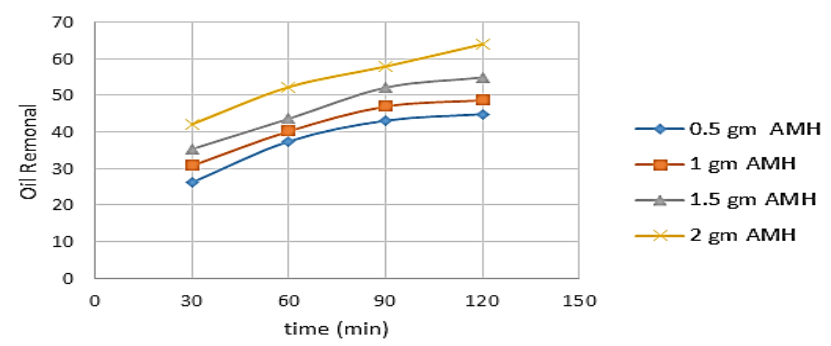

Figure 3. Effect of dosage on organic removal in $0.075 \mathrm{~mm}$ activated moringa peels size, $\mathrm{pH}=6.2$, room temperature.

\subsection{Reaction time effect}

Contact time considered one of the most significant factors during adsorption process. It is well known, the removal rate of the pollutant and the adsorbent efficiency are increased with the increase of the contact time. During treatment process, the $\mathrm{MH}$ and $\mathrm{AMH}$ surface is continuously loaded by the pollutant molecules which lead to saturate the active sites of the adsorbent. After saturation, it is difficult for the adsorbent to uptake any more organic pollutant from the PW. The contact time effect on the removal of organic pollutant by $\mathrm{MH}$ and $\mathrm{AMH}$ is observed in Figures 4 and 5 . The results show the quantity of adsorbed organic pollutant is augmented by the beginning of the contact times. However, the adsorption rate is increased with contact time until $120 \mathrm{~min}$, later the increase in contact time has a limited effect on organic pollutant removal. This may be attributed to the huge free active sites are obtainable at an early stage of treatment then these available sites are reduced as result of organic pollutant adsorption (Mohammed and Baytak, 2016). Subsequently attainment the plateaus, the equilibrium are attained about $35 \mathrm{~min}$ at $2 \mathrm{gm}$ adsorbed organic. All the tests are approved out through $2 \mathrm{~h}$ of contact time to find equilibrium at the solid/liquid interface. It is obvious that there is no change in organic removal when the time is lengthy (Hosny et al., 2016) and (Haider T. Naeem and Ali A. Hassan, 2018).

\section{4. $\mathrm{pH}$ effect}

Solution $\mathrm{pH}$ is an important variable to consider during the adsorption treatment process. The adsorption of organic content from $\mathrm{PW}$ aqueous solutions on the $\mathrm{MH}$ and $\mathrm{AMH}$ were investigated in the $\mathrm{pH}$ range of $2-10$. Figures 6 and 7 demonstrate the effect of $\mathrm{pH}$ on the removal of organic content from PW aqueous solutions. The result reveals that adsorption process is favored the acidic medium solution. The removal efficiency of organic pollutant increased as a result of $\mathrm{pH}$ decreasing. While organic exclusion was $83.2 \%$, 94\% at $\mathrm{pH} 2$ and 20.7\%, 43\% for HM and AHM at $\mathrm{pH} 10$. This result is in agreement with previous reported works, where similar trend was stated for adsorption of organic content on moringa peels waste (Dan and Chattree, 2018) and (George et al., 2016). The surface of adsorbents was negatively charged as the $\mathrm{pH}$ solution increased from 2.0 to 6.0. The functional groups of the HM and AHM were more deprotonated and therefore it is available for the organic content. Reduction in bio adsorption harvest at higher $\mathrm{pH}$ $(\mathrm{pH}>6)$ is not only connected the formation of solvable hydroxylated complexes of the organic compounds (Munagapati et al., 2010).

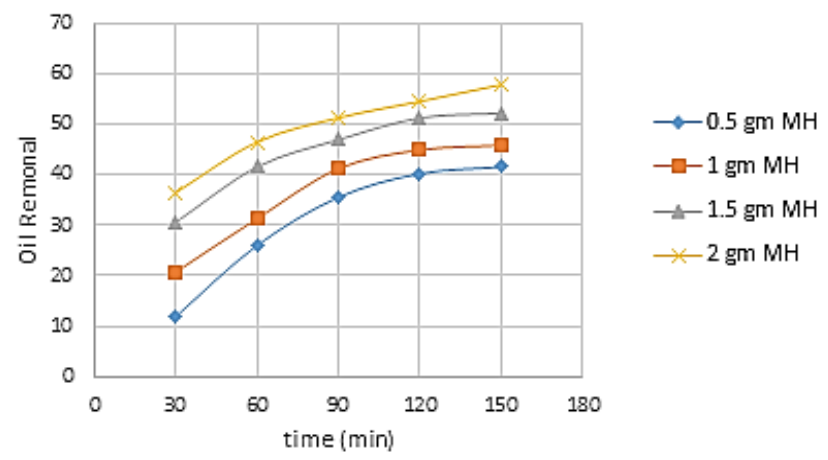

Figure 4. Effect of contact time on organic removal in $0.075 \mathrm{~mm}$ moringa peels size, $\mathrm{pH}=6.2$, room temperature.

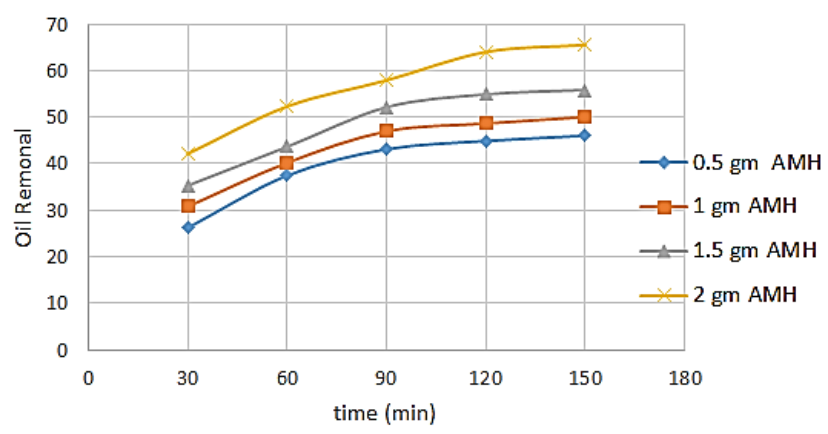

Figure 5. Effect of contact time on organic removal in $0.075 \mathrm{~mm}$ activated moringa peels size, $\mathrm{pH}=6.2$, room temperature.

\subsection{Adsorption isotherms}

Reactions between solutes and the surfaces of solids play a vital character in the waste treatment chemistry. Adsorption equilibria provide fundamental physicochemical information to evaluate the applicability of the adsorption process. The adsorption isotherms exemplify the relations between equilibrium concentrations of adsorbate in the solid phase and in the liquid phase at constant temperature. The delivery of contaminant such as organic between the adsorbent and the PW solution below equilibrium conditions is significant in sympathetic the capacity of the adsorbent for the organic elimination (Ardejani et al., 2007) and (Ali Saleh Jafer et al., 2019). The relationship between the quantities of the oil field pollutant adsorbed and the concentration at 
equilibrium was investigated using the linear form of the Langmuir and Freundlich isotherms, the most commonly used adsorption isotherm models (Yu et al., 2016) and (EI Messaoudi et al., 2016).

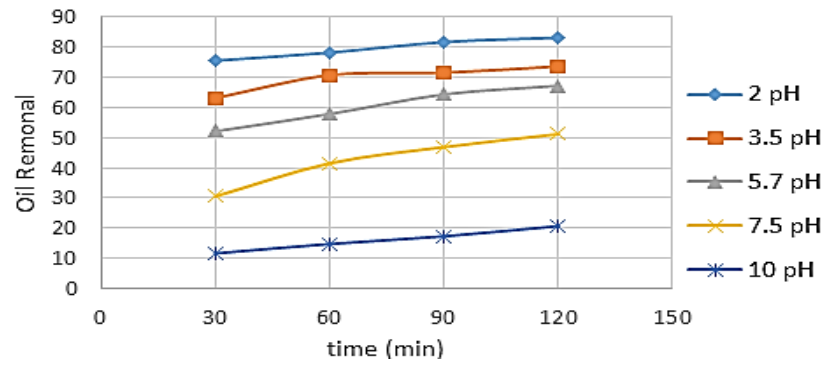

Figure 6. Effect of $\mathrm{pH}$ on organic removal in $0.075 \mathrm{~mm}$ moringa peels size, $1.5 \mathrm{gm}$ dosage, room temperature, and $120 \mathrm{~min}$ contact time.

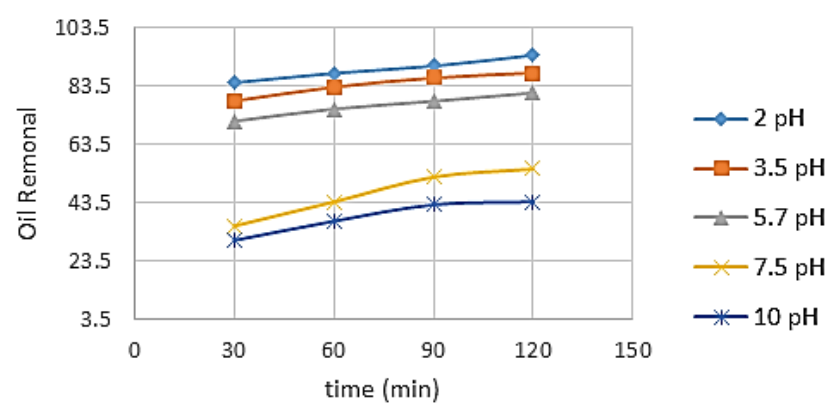

Figure 7. Effect of $\mathrm{pH}$ on organic removal in $0.075 \mathrm{~mm}$ activated moringa peels size, $1.5 \mathrm{~g}$ dosage, room temperature, and 120 min contact time.

Langmuir isotherm:

$$
\mathrm{q}_{\mathrm{e}}=\left(\mathrm{q}_{\mathrm{m}} \mathrm{K}_{\mathrm{L}} \mathrm{C}_{\mathrm{e}}\right) /\left(1+\mathrm{K}_{\mathrm{L}} \mathrm{C}_{\mathrm{e}}\right)
$$

Freundlich isotherm:

$$
\mathrm{q}_{\mathrm{e}}=\mathrm{K}_{\mathrm{F}}\left(\mathrm{C}_{\mathrm{e}}\right)^{1 / \mathrm{n}}
$$

where, $q_{e}(\mathrm{mg} / \mathrm{g})$ is the quantity of organic content per unit weight of adsorbent at equilibrium concentration, $\mathrm{Ce}$ (ppm). The $\mathrm{q}_{\mathrm{m}}(\mathrm{mg} / \mathrm{g})$ and $\mathrm{kL}(\mathrm{L} / \mathrm{mg})$ are the Langmuir coefficients connected to the maximum monolayer capacity and energy of adsorption, correspondingly. The $\mathrm{K}_{\mathrm{F}}$ and $1 / \mathrm{n}$ are Freundlich coefficients connected to adsorption capacity and intensity of adsorption correspondingly. Langmuir isotherm shoulders a monolayer adsorption surface deprived of slightly lateral contact between adsorbed molecules (Anirudhan and Sreekumari, 2011). The adsorption data for HM and AHM were fitted into Langmuir and Freundlich isotherm equations. The maximum adsorption on moringa peels and activated moringa peels were found to be 22.88 and 26.88 $\mathrm{mg} / \mathrm{g}$. It seems that the Langmuir model provided a better fits than Freundlich model over the experimental range with correlation coefficient $\left(R^{2}>0.99\right)$. This result is similar to Aseel M. et al., (Aljeboree et al., 2017). Figures 8 and 9 show the Langmuir model for HM and AHM respectively. The Freundlich model correlation coefficient is lower than that of Langmuir model with $\mathrm{R}^{2}(0.9545)$. The limits of $\mathrm{K}_{\mathrm{F}}$ and $1 / n$ showed penetrating alteration at higher temperatures. The standards of $1 / \mathrm{n}(0.1<1 / \mathrm{n}<1)$ provide a promising adsorption of organic compounds at experimental conditions as shown in Figures 10 and 11.

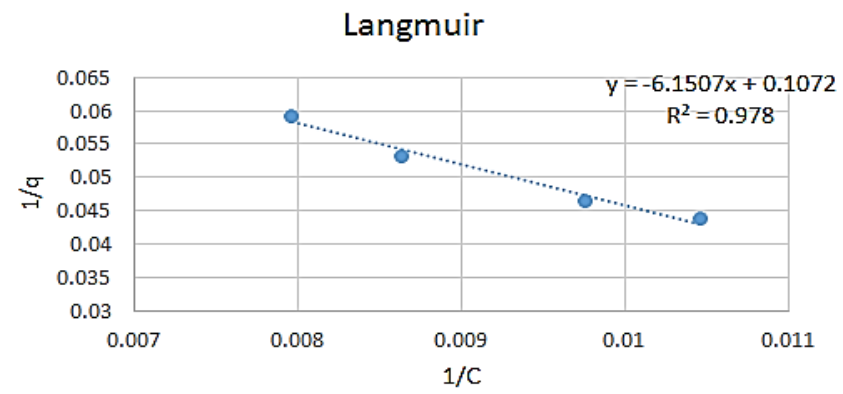

Figure 8. Langmuir isotherm plot for moringa peels adsorption of organic content on produced water sample.

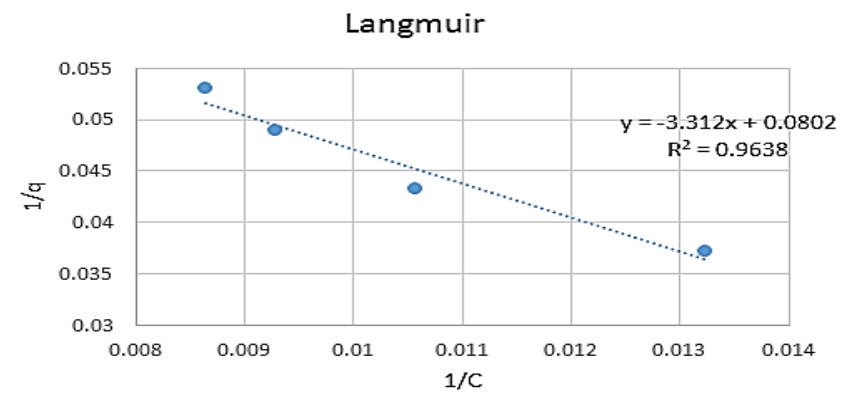

Figure 9. Langmuir isotherm plot for activated moringa peels adsorption of organic content on produced water sample.

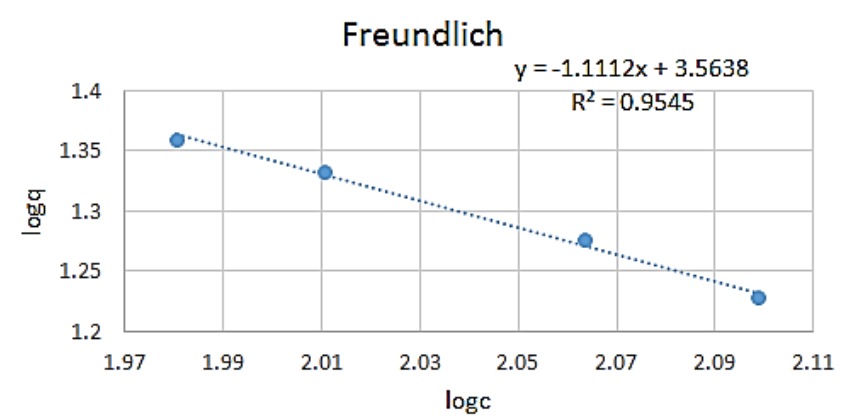

Figure 10. Freundlich isotherm plot for moringa peels adsorption of organic content on produced water sample.

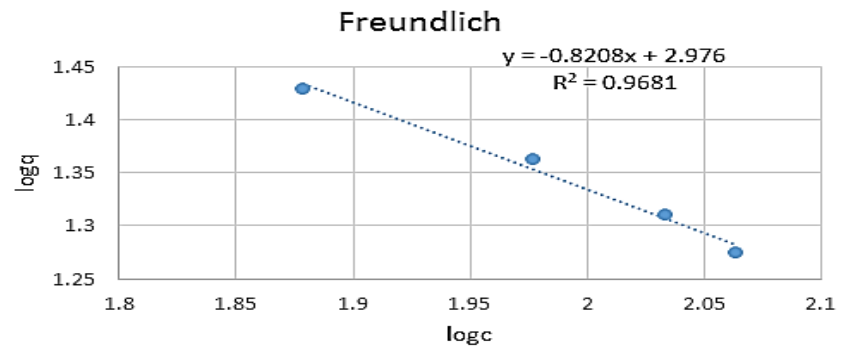

Figure 11. Freundlich isotherm plot for activated moringa peels adsorption of organic content on produced water sample. 


\section{Conclusions}

Activated moringa peels were found to have a good adsorbent for the elimination of organic content from oilfield produced water. Results show the sorption was depended on solution $\mathrm{pH}$, adsorbent dose and contact time of the adsorbent. The quantity of adsorption capacity $(\mathrm{mg} / \mathrm{g})$ was improved with increase the adsorbent dosage. Adsorption of organic content follows the Langmuir isotherm. This work showed that the moringa and activated moringa peels are ecofriendly adsorbents can suggest for the treatment of produced water. In addition, moringa peels are available in large amount and its treatment technique is very economical.

\section{Acknowledgements}

The authors thank for Al-Muthanna university (collage of engineering), Al-Qasim Green University (collage of water resources engineering) and Ministry of Higher Education Iraq for support this research.

\section{References}

Abdelwahab O., Nasr S.M. and Thabet W.M. (2017), Palm fibers and modified palm fibers adsorbents for different oils, Alexandria Engineering Journal, 56, 749-755.

AbdurRahman F.B., Akter M. and Abedin M.Z. (2013), Dyes removal from textile wastewater using orange peels, International Journal of Scientific \& Technology Research, 2, 47-50.

Ahsan M.A., Katla S.K., Islam M.T., Hernandez-Viezcas J.A., Martinez L.M., Díaz-Moreno C.A., Lopez J., Singamaneni S.R., Banuelos J. and Gardea-Torresdey J. (2018), Adsorptive removal of methylene blue, tetracycline and $\mathrm{Cr}(\mathrm{VI})$ from water using sulfonated tea waste, Environmental Technology \& Innovation, 11, 23-40.

Al-Anber Z.A. and Al-Anber M.A. (2008), Thermodynamics and kinetic studies of iron(III) adsorption by olive cake in a batch system, Journal of the Mexican Chemical Society, 52, 108-115.

Hassan A.A., Naeem H.T. and Hadi R.T. (2018), Degradation of oily waste water in aqueous phase using solar $\left(\mathrm{ZnO}, \mathrm{TiO}_{2}\right.$ and $\mathrm{Al}_{2} \mathrm{O}_{3}$ ) catalysts, Pakistan Journal of Biotechnology 15, 909-916.

Jafer A.S., Hassan A.A. and Naeem Z.T. (2019), A study on the potential of moringa seeds in adsorption of organic content from water collected from oilfield refinery.

Ali R.M., Hamad H.A., Hussein M.M. and Malash G.F. (2016), Potential of using green adsorbent of heavy metal removal from aqueous solutions: adsorption kinetics, isotherm, thermodynamic, mechanism and economic analysis, Ecological Engineering, 91, 317-332.

Aljeboree A.M., Alshirifi A.N. and Alkaim A.F. (2017), Kinetics and equilibrium study for the adsorption of textile dyes on coconut shell activated carbon, Arabian Journal of Chemistry, 10, S3381-S3393.

Almarouf H.S., Nasser M.S., Al-Marri M.J., Khraisheh M. and Onaizi S.A. (2015), Demulsification of stable emulsions from produced water using a phase separator with inclined parallel arc coalescing plates, Journal of Petroleum Science and Engineering, 135, 16-21.

Al-Othman Z.A., Ali R. and Naushad M. (2012), Hexavalent chromium removal from aqueous medium by activated carbon prepared from peanut shell: adsorption kinetics, equilibrium and thermodynamic studies, Chemical Engineering Journal, 184, 238-247.

Amuda O. and Amoo I. (2007), Coagulation/flocculation process and sludge conditioning in beverage industrial wastewater treatment, Journal of Hazardous Materials, 141, 778-783.

Anirudhan T.S. and Sreekumari S.S. (2011), Adsorptive removal of heavy metal ions from industrial effluents using activated carbon derived from waste coconut buttons, Journal of Environmental Sciences, 23, 1989-1998.

Ardejani F.D., Badii K., Limaee N.Y., Mahmoodi N.M., Arami M., Shafaei S.Z. and Mirhabibi A.R. (2007), Numerical modelling and laboratory studies on the removal of Direct Red 23 and Direct Red 80 dyes from textile effluents using orange peel, a low-cost adsorbent, Dyes Pigments, 73, 178-185.

Aziz A.A. and Daud W.M.A.W. (2012), Oxidative mineralisation of petroleum refinery effluent using Fenton-like process, Chemical Engineering Research and Design, 90, 298-307.

Bakke T., Klungs $\varnothing y r$ J. and Sanni S. (2013), Environmental impacts of produced water and drilling waste discharges from the Norwegian offshore petroleum industry, Marine Environmental Research, 92, 154-169.

Bello O.S., Adegoke K.A. and Akinyunni O.O. (2017), Preparation and characterization of a novel adsorbent from Moringa oleifera leaf, Applied Water Science, 7, 1295-1305.

Benitez F.J., Acero J.L., Gonzalez T. and Garcia J. (2001), Organic matter removal from wastewaters of the black olive industry by chemical and biological procedures, Process Biochemistry, 37, 257-265.

Boudrahem F., Aissani-Benissad F. and Soualah A. (2015), Removal of basic yellow dye from aqueous solutions by sorption onto reed as an adsorbent, Desalination and Water Treatment, 54, 1727-1734.

da Silva S.S., Chiavone-Filho O., de Barros Neto E.L. and Foletto E.L. (2015), Oil removal from produced water by conjugation of flotation and photo-Fenton processes, Journal of Environmental Management, 147, 257-263.

Dan S. and Chattree A. (2018), Sorption of fluoride using chemically modified Moringa oleifera leaves, Applied Water Science, 8, 76.

Diya'uddeen B.H., Daud W.M.A.W. and Aziz A.A. (2011), Treatment technologies for petroleum refinery effluents: a review, Process Safety and Environmental Protection, 89, 95-105.

El Messaoudi N., El Khomri M., Bentahar S., Dbik A., Lacherai A. and Bakiz B. (2016), Evaluation of performance of chemically treated date stones: Application for the removal of cationic dyes from aqueous solutions, Journal of the Taiwan Institute of Chemical Engineers, 67, 244-253.

El-Din G.A., Amer A.A., Malsh G. and Hussein M. (2017), Study on the use of banana peels for oil spill removal, Alexandria Engineering Journal.

Fakhru'l-Razi A., Pendashteh A., Abdullah L.C., Biak D.R.A., Madaeni S.S. and Abidin Z.Z. (2009), Review of technologies for oil and gas produced water treatment, Journal of Hazardous Materials, 170, 530-551.

Fathy M., El-Sayed M., Ramzi M. and Abdelraheem O.H. (2017), Adsorption separation of condensate oil from produced water using ACTF prepared of oil palm leaves by batch and fixed bed techniques, Egyptian Journal of Petroleum. 
Fiset J.F., Tyagi R.D. and Blais J.-F. (2002), Cocoa shells as adsorbent for metal recovery from acid effluent, Water Quality Research Journal, 37, 379-388.

Fouad Y.O. (2014), Separation of cottonseed oil from oil-water emulsions using electrocoagulation technique, Alexandria Engineering Journal, 53, 199-204.

George K.S., Revathi K.B., Deepa N., Sheregar C.P., Ashwini T.S. and Das S. (2016), a study on the potential of Moringa leaf and bark extract in bioremediation of heavy metals from water collected from various lakes in Bangalore, Procedia Environmental Sciences, 35, 869-880.

Gupta N., Kushwaha A.K. and Chattopadhyaya M.C. (2016), Application of potato (Solanum tuberosum) plant wastes for the removal of methylene blue and malachite green dye from aqueous solution, Arabian Journal of Chemistry, 9, S707S716.

Naeem H.T. and Hassan A.A. (2018), Effectiveness \& economy of sawdust wood adsorbents in removing anionic dyes of aqueous solutions, Pakistan Journal of Biotechnology, 15, 311-320.

Hernández-Francisco E., Peral J. and Blanco-Jerez L.M. (2017), Removal of phenolic compounds from oil refinery wastewater by electrocoagulation and Fenton/photo-Fenton processes, Journal of Water Process Engineering, 19, 96-100.

Hosny R., Fathy M., Ramzi M., Moghny T.A., Desouky S.E.M. and Shama S.A. (2016), Treatment of the oily produced water (OPW) using coagulant mixtures, Egyptian Journal of Petroleum, 25, 391-396.

Ibrahim S., Wang S. and Ang H.M. (2010), Removal of emulsified oil from oily wastewater using agricultural waste barley straw, Biochemical Engineering Journal, 49, 78-83.

Mousa K.M. and Al-Hasan A.A. (2017), Oilfield Produced Water Treatment by Coagulation/Flocculation Processes, Second Conf. Post Grad. Res. CPGR2017 Coll. Eng. Al-Nahrain Univ Baghdad Iraq.

Lee S.-Y. and Park S.-J. (2013), $\mathrm{TiO}_{2}$ photocatalyst for water treatment applications, Journal of Industrial and Engineering Chemistry, 19, 1761-1769.

Li Q., Kang C. and Zhang C. (2005), Waste water produced from an oilfield and continuous treatment with an oil-degrading bacterium, Process Biochemistry, 40, 873-877.

Mohammed M.I. and Baytak S. (2016), Synthesis of bentonitecarbon nanotube nanocomposite and its adsorption of rhodamine dye from water, Arabian Journal for Science and Engineering, 41, 4775-4785.

Mohammed T.J. and Shakir E. (2017), Effect of settling time, velocity gradient, and camp number on turbidity removal for oilfield produced water, Egyptian Journal of Petroleum.

Munagapati V.S., Yarramuthi V., Nadavala S.K., Alla S.R. and Abburi K. (2010), Biosorption of $\mathrm{Cu}(\mathrm{II}), \mathrm{Cd}(\mathrm{II})$ and $\mathrm{Pb}(\mathrm{II})$ by Acacia leucocephala bark powder: Kinetics, equilibrium and thermodynamics, Chemical Engineering Journal, 157, 357-365.

Okiel K., El-Sayed M. and El-Kady M.Y. (2011), Treatment of oilwater emulsions by adsorption onto activated carbon, bentonite and deposited carbon, Egyptian Journal of Petroleum, 20, 9-15.

Ratnamala G.M., Deshannavar U.B., Munyal S., Tashildar K., Patil S. and Shinde A. (2016), Adsorption of reactive blue dye from aqueous solutions using sawdust as adsorbent: optimization, kinetic, and equilibrium studies, Arabian Journal for Science and Engineering, 41, 333-344.

Saien J. and Nejati H. (2007), Enhanced photocatalytic degradation of pollutants in petroleum refinery wastewater under mild conditions, Journal of Hazardous Materials, 148, 491-495.

Steevensz A., Madur S., Feng W., Taylor K.E., Bewtra J.K. and Biswas N. (2014), Crude soybean hull peroxidase treatment of phenol in synthetic and real wastewater: Enzyme economy enhanced by Triton X-100, Enzyme and Microbial Technology, 55, 65-71.

Vieira A.M.S., Vieira M.F., Silva G.F., Araújo Á.A., Fagundes-Klen M.R., Veit M.T. and Bergamasco R. (2010), Use of Moringa oleifera seed as a natural adsorbent for wastewater treatment, Water, Air, \& Soil Pollution, 206, 273-281.

Yu H., Pang J., Ai T. and Liu L. (2016), Biosorption of Cu2+, Co2+ and $\mathrm{Ni} 2+$ from aqueous solution by modified corn silk: Equilibrium, kinetics, and thermodynamic studies, Journal of the Taiwan Institute of Chemical Engineers, 62, 21-30.

Zoubeik M., Ismail M., Salama A. and Henni A. (2017), New developments in membrane technologies used in the treatment of produced water: A review, Arabian Journal for Science and Engineering, 1-26.

Zsirai T., Qiblawey H., Buzatu P., Al-Marri M. and Judd S.J. (2018), Cleaning of ceramic membranes for produced water filtration, Journal of Petroleum Science and Engineering 166, 283-289. 